\title{
Introduction
}

\section{Speaking to the Eye}

\author{
BRUCE BuCHAN AND DAVID ELLISON \\ GRIFFITH UNIVERSITY
}

In an obscure footnote to his entrepreneurial proposal for a multipurpose institution tellingly labelled the Panopticon, Jeremy Bentham wrote his epigrammatic injunction to the modern age: 'lose no occasion of speaking to the eye'. ${ }^{1}$ The phrase was deliberately declaratory, and it contained an inherent sensory hierarchy. Power was to be registered through the eye, by seeing and by making visible. Aural sensation, by speaking, was referred to only metaphorically. In this paradigm, the sound of power was subordinate to the power of vision. If Lord Chancellor Bacon's legal maxim was 'Nihil ex scenâ' (nothing outside of the public eye), Bentham asserted his must be 'Multum ex scenâ' (everything outside of the public eye).2

This hierarchy was implicit in Bentham's purpose to recommend that in the operations of the law and the punishment of offenders (with which he was primarily concerned in recommending the Panopticon), theatre was everything. The awful majesty of the law as well as the abject guilt of the offender must be seen, and it was by seeing along carefully constructed but otherwise invisible lines of sight built into the institution that the Panopticon itself would function. The Panopticon would manifest law and justice, morality and order in carefully designated fields of vision. 
The knowledge of being held in sight, that one was observed or observable at any moment, was Bentham's alternative to the inefficiency of 'torture' and cruelty by whips and chains in the existing prisons he wanted to replace. Held in sight within the walls of their cells, but otherwise unrestrained by torturing chains, Bentham suggested that 'noise' was the 'only offence' to which 'troublesome' inmates could resort, an offence that could easily be 'subdued by gagging'. ${ }^{3}$

In its inscription of vision into the design of the institution, a design transferrable to other uses including hospitals and factories, Bentham's Panopticon has famously been read as the incarnation of visual power, through surveillance, in modern societies. ${ }^{4}$ More recent critics have suggested that the disciplinary power of surveillance (of the many by the few) has been replaced by the no-less disciplined and disciplinary orchestration of spectacle (the exposure of the few to the many). ${ }^{5}$ In terms of either surveillance or spectacle, modernity has been portrayed as an age of vision par excellence, in which both power and possibility are primarily conveyed visually. This interpretation has been consolidated by a body of work in historical sensory studies which has tended to concentrate on vision over sound and the other senses, emphasising the importance of spectatorship in the expression of civility and politeness. ${ }^{6}$ The behavioural emblem of this body of work remains Adam Smith's tying of civil conduct to the ability to take the position of a 'cool and impartial spectator' in his Theory of Moral Sentiments. ${ }^{7}$ In Smith's view, the approbation of social passions and disapprobation of unsociable, disruptive passions depended on our ability to see ourselves as an 'indifferent by-stander' judging the conduct of others before us, and thus internalising indifferent judgement by spectating upon our own conduct. ${ }^{8}$ In this sense, the impartial spectator occupied a position akin to the inmate in Bentham's Panopticon. By internalising the experience of being gazed at, both were forever gazed upon by themselves. Here the force of morality was explicitly tied to the power of vision:

The man who has broke through all those measures of conduct, which can alone render him agreeable to mankind, though he should have the most perfect assurance that what he had done was for ever to be concealed from every human eye, it is all to no purpose. When he looks back upon it, and views it in the light in which the impartial spectator would view it, he finds that he can enter into none of the motives which influenced it. ${ }^{9}$ 
Indeed, Smith explicitly contrasted the powerful silence of internalised impartial spectatorship to the mere 'noise' of external sources of moral judgement:

if the man within condemns us, the loudest acclamations of mankind appear but as the noise of ignorance and folly, and whenever we assume the character of this impartial judge, we cannot avoid viewing our own actions with his distaste and dissatisfaction. The weak, the vain, and the frivolous, indeed, may be mortified by the most groundless censure, or elated by the most absurd applause. Such persons are not accustomed to consult the judge within concerning the opinion which they ought to form of their own conduct. 10

The project to return sound to critical consciousness seeks to redress the apparent overvaluation of the visual in accounts of the emergence of Modernity. The coherence and persuasiveness of these accounts rest unsustainably, so the argument goes, on a general impoverishment of the other senses, notably the acoustic. We are asked to incredulously observe the relative silence of Western history, and return to the archive with ears newly opened to the past and present. This general invitation to attend to a host of muted, ignored or suppressed sounds has been taken up in work appearing in the fields of cultural theory, literary and film studies, cultural history, and the anthropology of the senses. To offer but one example, Murray Schafer's groundbreaking The Soundscape called for just such an acknowledgment of the sonic dimension of history while also reflecting on the ear's particular vulnerability to the welter of noises that threaten to overwhelm at every turn. ${ }^{11}$ In this regard, Schafer is party to a much older tradition of the sonically beleaguered; those who wish to both recover and advocate for a contemplative relationship to sound in the face of apparently indiscriminate and impinging noise. The long history of similarly afflicted writers suggests a promising point of entry for thinking about what noise might mean for those who make it, hear it, harness its metaphorical energies or are tasked with its management. Early entries in what must now be recognised as a distinct genre of principally urban complaint include works by Dickens, Babbage, James Sully and Schopenhauer.

Schopenhauer's essay, 'On Noise', draws a stark dividing line between those who are sensitive to noise and those who are not. The former find themselves subjected to a host of interruptions that, in turn, wreak havoc on their capacity for 
roomy, synthesising thought. In the face of interminable noise, the mind loses both value (like a large diamond cut into smaller pieces), and power (like an army dissolving under the scattering of troops). ${ }^{12}$ Noise, which is of course a necessarily fluid and partial term, assumes a destructive solidity among those who suffer its effects. In Peter Bailey's useful summary it is 'a broad yet imprecise category of sounds that register variously as excessive, incoherent, confused, inarticulate or degenerate'.13 Noise is a vexatious fault line between nuisance and purpose, labour and rest, pleasure and pain. Schopenhauer's complaint, which predictably rounds on the injuries those who work with their hands inflict on those who work with their heads, captures something of the complex, overdetermined nature of noise and its reception. Noise distinguishes between the classes while also opening an imaginative pathway into the supposedly coarser sensorium of the labourer, which may be intimately documented without the corresponding demand of political sympathy. Which is to say, the noise-afflicted never cease to speculate on the lives of the noise-makers, and their rooted indifference-or worse-their positive pleasure in the face of din. In his 1878 essay 'Civilisation and Noise' (the terms are diametrically opposed) the Victorian psychologist James Sully considered the density of urban life from the perspective of the variable sensitivity to noise:

The man with a finely set, musical ear has practically to live with barbarians who actually take pleasure in harsh and unlovely sounds, and with many more semi-civilised who are quite indifferent to such noises. Not only children but adults love to tease and excite their dogs, and this seems to show that they positively enjoy the sensations of loud sound which they thus evoke. The fondness of a certain class of people for screaming birds points to the same primitive conditions of sensibility. ${ }^{14}$

Noise not only differentiates between peoples, but the act of registering its supposedly destructive presence serves as a sensitive index to the decline of rights as yet unnamed and without recourse to legal enforcement. Before the advent of noise ordinance laws in the twentieth century, these socially aggrieved authors had few options but to suffer, and document, in terms that variously described their vulnerability to the city, the national temperament, even the sound of the historical moment. Hostilities over the composition of the urban soundscape continue to influence the way we think about noise in an adversarial light, but there are parallel 
developments in the history of sound where noise-particularly in its convivial and exuberant forms - could be taken as a sign of civility, urbanity, creativity, even sublimity. Although here too the semiotic instability of noise makes it difficult to contrast punitive, disciplinary approaches to excess sound against more liberal and supportive regimes. This confounding quality of noise, its pervasive troubling of the apparent purity of its diametrically opposed alternatives-silence, music, polite discourse, and so on-invites a more thorough consideration of its various forms, values and histories. The essays that make up this special section address noise through a series of case studies ranging from Socratic dialogue to unmuffled engines in full roar.

Marie Thomson argues for a more generous explanation of noise that evades the narrower dictates of an aesthetic moralism that privileges silence over din. Noise need not be heard as necessarily destructive; a model that relies on the stability of both an emitting source and a pained receiver. Instead, Thompson conceives of noise as an interruption to a set of relationships that induces a modification in bodies and systems. As such, noise has an intimate connection to affect in that it has no point of origin and sits outside of the symbolic. Affect does not cleave to an object or subject; it is rather a transitional movement between states. Thinking of noise in these terms releases us from conventional policing responses that focus on the identification and containment of the noise-source. That is to say, that conceiving of noise as, in Thompson's neat formulation, an affect with effects, removes the human ear as the privileged site of reception, identification and judgment of noise. In lieu of judgment, Thompson imagines a radical openness to noise's potential.

Bruce Buchan's essay is similarly open to a positive valuation of noise in the context of recovering an acoustic dimension in the history of political thought. The public communication of political ideas in monological tirade or in crowded protest is an inherently noisy activity, but Buchan argues for a wider receptivity to noise. By speaking of noise he questions the normative privileging of the sound of dialogue in Western political thought. Dialogue is typically represented as an archetypal political sound in which what is heard are the varied meanings conveyed in the measured public exchange of arguments, thought by some to constitute the essence of democracy. Buchan argues that political noise should be listened to as well, not only in the grammar and syntax of words and sentences, but in the varied contexts 
in which speech, protest, oratory, instruction or interjection are performed. Crucially, it is in the imaginative invocation of the noises of these contexts that meaning is inscribed in written texts through the legitimation of particular kinds of speech and speakers.

Where Buchan surveys political noise across centuries of Western history, Vanessa Agnew, Peter Denney, Helen Groth and David Ellison bring a more detailed focus to selected soundscapes of eighteenth- and nineteenth-century Europe. Vanessa Agnew reconsiders the grand tour as a sonic experience through the specific, but also characteristically representative, figure of Goethe. Agnew attends to the sociable conversations on the road, the explicitly sought auditory experiences and the insistent and continuous presence of music by way of demonstrating the centrality of sound to the tour. Using a sustained focus on the messy, sometimes contradictory accounts offered by Goethe's Italian Journey, among other first-hand testimony, Agnew explores what it meant to listen in the eighteenth century.

Peter Denney also attends to the sociable noise of conversation, music and song but here as it defined the soundscape of English rural life in the first half of the eighteenth century. For poets, these exuberant sounds lent themselves to the task of expressing the fertility of the land, the joy of the harvest and, cumulatively, the greatness of Britain itself. By the century's end the now enclosed and improved fields had fallen silent, shifting the terms by which the landscape could be apprehended from the acoustic to the visual. As Denney explains, these hushed fields emerged from a newly individualised and proprietorial approach to land that valued the visible appearance of order. In this context the silent landscape not only provided an emphatic contrast to the clamour of the industrial city, but was made available as a sign of civilisation. The focus then shifts towards the early Australian colonies and an exploration of how the moral and aesthetic values attributed to English agricultural fields, first as sociable soundscapes and then as silenced parks, authorised the colonists to exercise authority over Indigenous lands.

Helen Groth takes up the question of this distinction between noise and order in her account of the complex and productive imbrication of photography and textbased voice transcription technologies in the work of Henry Mayhew. Drawing on the work of the influential Victorian psychologist James Sully, Groth aligns Mayhew's commitment to the mimetic capture of London street voices with what she calls 'the 
emerging discursive nexus' between noise and civilisation. The silence of print simultaneously impedes, but also invites, access to an uncivil soundscape seemingly captured by the promise of transcription. Here Groth traces the rise of 'a distinctively modern take on the struggle to hear what can no longer be heard'. In the documentary impulse revealed in Mayhew's alignment of text and image as the desire to fix a moment in time, Groth detects a new impulse, a way of thinking about the voice not as irretrievable, but as peculiarly susceptible to the materialities of new media.

David Ellison also considers emergent forms of sonic technology in his account of incidental machine noise in eighteenth- and nineteenth-century automata. Contemporary audiences for automata performance demonstrated a capacity to filter or neutralise extraneous noise that otherwise threatened to interfere with the narrative content of the demonstration. These audiences suggest affinities with those gathered at musical concerts, which similarly learned to suppress the unavoidable noise associated with performance. Ellison charts the way that automata noise came to signify etherealised human machine interaction, thus offering an alternative to conventional renderings of industrial labour. He suggests that recovering the reception contexts of automata sound offers insights into the development of white noise and the promotion of modern corporate productivity.

The final group of essays highlights the continuing relevance of normative judgments about noise and silence as important legal and cultural phenomena. Katherine Biber explores the legal right to silence framed by the considerable noise provoked by a defendant's refusal to speak. Her article attends to the profound gap between legal responses to silence, and the status of silence in literature, linguistics and philosophy. Under the rules of evidence, for example, what may not be inferred from silent testimony is made explicit, whereas conversationally a silent interlocutor provokes wide-ranging and intense speculation. Biber reads legal cases with an ear to the noise produced by the defendant at the time of the crime, and in the period leading up to their appearance in court-a period under which the defendant's intermittent silence was treated inferentially. It is only on entering the court that the meaning of silence is dramatically constricted, as juries are instructed what they may and may not understand by the absence of speech. Biber argues 'Law's commentary forecloses the possibility that silence might be deliberately 
ambiguous, that it might invite speculation, or that inferences demand to be drawn from it'.

In their jointly authored article, Alexandra Brown and Andrew Leach seize on Italian historian Manfredo Tafuri's metaphorical distinction between silence and noise. Tafuri has two contrasting tendencies in Italian architecture in mind: one is open and integrative, the other introspective and concerned with autonomy. Brown and Leach assign the works of selected architects under these headings, less in the spirit of taxonomy than to consider how these critical concepts might give shape to the trajectory of architecture since the 1970s.

Finally, Melissa Bull considers Australian legislative responses to the phenomenon of 'hooning' since the 1990s. She traces the origins and effects of a framework of laws in a variety of jurisdictions that locate the 'hoon' as a noisy and criminal disturber of public peace in their penchant for 'souped-up' cars, revving engines, loud music and street racing. Yet the punitive responses to this noisy crime are out of proportion to its actual danger to public safety. The disproportionate response, she argues, belies a neoliberal acoustic politics focused on securing sequestered urban spaces and quietening unregulated noises within them.

In drawing together this selection of essays from across the humanities and social sciences, this special section of Cultural Studies Review attests to the historical and contemporary contingency of 'noise' as a phenomenon that (almost literally) cries out for further investigation. While noise and sound have regularly been paired as opposite normative and aesthetic poles on the sonic spectrum, the essays in this issue each point toward the need for a more complicated appraisal of this pairing. The normative or aesthetic privileging of sound (in speech or in music) prevents a more positive evaluation of noise as a phenomenon worthy of further historical investigation, or as a marker of human ingenuity and industry or as the means through which restricted speech is opened to genuinely public participation. In each of these ways, the essays in this collection use noise as an object of investigation that cuts across otherwise neatly defined domains of law, politics, architecture and literature. In pushing the boundaries of their own disciplinary fields in this way, this collection also serves as a timely reminder of the value and the viability of interdisciplinary research in Australia. 
-NOTES

We would like to thank the School of Humanities at Griffith University and the Griffith Centre for Cultural Research for making this publication possible by providing funding for the 2011 symposium at which these papers were first presented. We would also like to thank our contributors who responded so thoughtfully to our editorial suggestions. Bruce Buchan, David Ellison and Peter Denney's research profiled in this special edition will be further supported by an Australian Research Council grant 'Policing Noise: The Sounds of Civility in British Discourse, c. 1700-1850'.

1 Jeremy Bentham, Panopticon; Or, the Inspection House, in The Works of Jeremy Bentham, vol. IV, ed. J. Bowring, William Tate, Edinburgh, 1843, p. 954.

2 Bentham, p. 954. Bentham's attribution to Bacon may have been a bowdlerised version of the maxim, 'nihil habeat forum ex scena' (the court has nothing to do with what is not before it). Francis Bacon, 'A Proposition to His Majesty, by Francis Bacon, Knight, ...Touching the Compiling and Amendment of the Laws of England', in The Works of Francis Bacon, Lord Chancellor of England, vol. V, William Pickering, London, 1826, p. 349.

3 Bentham, p. 84.

4 Michel Foucault, Discipline and Punish, The Birth of the Prison, Allen Lane, London, 1977, p. 201.

5 Zygmunt Bauman, Liquid Modernity, Polity, Cambridge, 2000, pp. 85-6; Guy Debord, Comments on the Society of the Spectacle, trans. M. Imre, Verso, New York, 1998; and Paul Virilio, The Vision Machine, Indiana University Press, Bloomington, 1994.

6 Peter De Bolla, The Education of the Eye: Painting, Landscape and Architecture in Eighteenth-Century Britain, Stanford University Press, Stanford, 2003.

${ }^{7}$ Adam Smith, The Theory of the Moral Sentiments, ed. D.D. Raphael and A.L. Macfie, Oxford University Press, Oxford, 1976 [1759], p. I, ii, 3.8, p. 24.

8 Smith, vol. 2, i, 1.7, p. 69 and vol. 3, i, 3, p. 110.

${ }_{9}$ Smith, vol. 3, 2.9, p. 118.

10 Smith, vol. 3, 2. 32, p. 130.

11 R. Murray Schafer, The Soundscape: Our Sonic Environment and the Tuning of the World, Inner Traditions, Rochester, 1994, pp. 3-12.

12 Arthur Schopenhauer, 'On Noise' in A. Schopenhauer, Studies in Pessimism: A Series of Essays, trans. G. Bailey Saunders, George Allen \& Co, London, 1913, pp. 127-33.

13 Peter Bailey, 'Breaking the Sound Barrier: A Historian Listens to Noise', Body and Society, vol. 2, no. 2, 1996, p. 50.

14 James Sully, 'Civilisation and Noise', Fortnightly Review, vol. 24, no. 143, November 1878, pp. 704-20. 